\title{
СОЦИАЛЬНЫЕ СТАНДАРТЫ КАЧЕСТВА ЖИЗНИ И ДЕМОГРАФИЧЕСКАЯ ПОЛИТИКА РЕСПУБЛИКИ БЕЛАРУСЬ В КОНТЕКСТЕ ВЫЗОВОВ УСТОЙЧИВОГО РАЗВИТИЯ
}

\author{
Мария ВЕРЕНИЧ ${ }^{\odot}$, научный сотрудник, \\ отдел культуры Института социологии НАН Беларуси
}

DOI: $\underline{\text { https://doi.org/10.36004/nier.cdr.2019.14-23 }}$

JEL Classification: J10, J18.

\begin{abstract}
В статье рассматриваются основные демографические вызовы Республики Беларусь в области численности и половозрастной структурь населения, области семьи $u$ рождаемости, в области смертности и продолжительности жизни населения, $a$ также миграции. Анализируется реализация демографической политики страны с учетом депопуляции, снижения рождаемости, ухудшения здоровья населения через призму качества жизни населения и т.д.
\end{abstract}

Ключевые слова: демография, устойчивое развитие, сочиальные стандарты, качество жизни, население, депопулящия.

The article describes the main demographic challenges of the Republic of Belarus related to population size and age-gender structure, family and birth rate, mortality and life expectancy, and migration. The implementation of the country's demographic policy is analysed considering depopulation, birth rate decrease, and deterioration in the population's health through the prism of the quality of life, etc.

Key words: demography, sustainable development, social standards, quality of life, population, depopulations.

Современные глобальные трансформации влияют как на уровень развития континентов и стран, так и на уровень и качество жизни отдельных их жителей. Качество жизни в свою очередь опосредует эволюцию демографических процессов, влияет на качество самого населения.

Демографические процессы середины XX начала XXI века в Республике Беларусь являются результатом трансформации геополитических, экономических, социальных, экологических и других факторов социальной жизни государства (последствия Великой Отечественной войны, перестройки, последствия Чернобыльской катастрофы, вхождения Беларуси в современные глобализационные процессы, распространение таких социально опасных заболеваний, как алкоголизм, наркомания, ВИЧ-инфекция и ряд других [3, с.21].

Страна входит в категорию стран демографического риска, когда не реализуется потенциальная социально-биологическая рождаемость учитывая структуру населения по полу, возрасту и брачному состоянию при условии полного исключения практики внутрисемейного ограничения рождаемости. Как отмечают специалисты, сегодня подавляющее большинство рождений - результат внутрисемейного регулирования деторождения, сознательного материнства.

Многие исследователи высказывают тревогу по поводу тех демографических процессов, которые в настоящее время происходят в республике. В первые десятилетия 21 века демографическая политика в Республике Беларусь обусловлена той ситуацией, которая сложилась в республике:

- в области численности и половозрастной структуры населения:

\footnotetext{
${ }^{\circ}$ Мария Веренич, lad05@yandex.ru
} 
$\checkmark$ быстро растущая депопуляция;

$\checkmark$ неблагоприятная возрастная структура населения (связанная, в первую очередь, со старением населения);

- в области семьи и рождаемости:

$\checkmark$ деградация института семьи (уменьшение числа браков, рост разводов); снижение уровней рождаемости (в результате чего не обеспечивается простое воспроизводство населения);

$\checkmark$ происходит ухудшение репродуктивного здоровья населения;

- в области смертности и продолжительности жизни населения:

$\checkmark$ ухудшение здоровья (физического, репродуктивного, психического) населения;

$\checkmark$ рост заболеваемости во всех возрастных группах, в особенности мужчин молодого трудоспособного возраста;

$\checkmark$ постоянный рост смертности,

$\checkmark$ снижение продолжительности жизни;

$\checkmark$ высокая по сравнению с развитыми странами детская (до 1 года) и материнская смертность;

- в области мигращии (внутренняя и внешняя):

$\checkmark$ отток сельской молодежи в города;

$\checkmark$ процесс депопуляции сельского населения (начался еще в 1972 году);

$\checkmark$ нарастает истощение демографической базы села;

$\checkmark$ продолжается отток молодежи и трудоспособного населения за пределы страны.

Общество и государство крайне заинтересованы в решении демографических проблем, в формировании такого типа воспроизводства населения, при котором рождаемость обеспечивала бы полное замещение родительских поколений, отсутствовала бы депопуляция, снижалась смертность и увеличивалась продолжительность жизни, укреплялась семья.

Следует отметить, что до начала 1990-х годов численность населения Беларуси постоянно росла благодаря накопленному ранее демографическому потенциалу. 1993 год является началом периода отрицательных демографических данных, сокращения численности населения страны: впервые за послевоенный период смертность превысила рождаемость, и страна вступила в качественно новый этап своего демографического развития - депопуляцию. Уже менее чем через 10 лет, в 2000 году число умерших превысило число родившихся в 1,5 раза. Одна из причин естественной убыли населения снижение числа родившихся за 1991-2001 годы более чем на треть. Как показали расчеты, 83 процента этого падения пришлось на первые пять лет, а 2/3 произошли за счет уменьшения рождаемости у городского населения.

Отражением готовности и заинтересованности в решении обозначенных проблем стало принятие 4 января 2002 года закона «О демографической безопасности Республики Беларусь» (первого на постсоветском пространстве), определившего правовые и организационные основы обеспечения демографической безопасности и поставившего задачу создания социально-экономических условий, достаточных для предупреждения и нейтрализации демографических угроз и формирования оптимального типа воспроизводства населения. Также при Совете Министров Республики Беларусь был организован Национальный комитет по народонаселению, являющийся постоянно действующим органом по проблемам государственной политики в сфере народонаселения, который осуществляет координацию политики в области демографической безопасности и выработку согласованных действий, направленных на обеспечение выполнения положений Закона «О демографической безопасности Республики Беларусь». В 2010 году была принята Концепция национальной безопасности Республики Беларусь, утвержденная Указом Президента 
Республики Беларусь от 9 ноября 2010 г. № 575, «являясь базисом для консолидации усилий личности, общества и государства в целях реализации национальных интересов... призвана обеспечить единство подходов к формированию и реализации государственной политики обеспечения национальной безопасности, а также методологическую основу совершенствования актов законодательства в различных сферах национальной безопасности, разработки документов стратегического планирования» $[5,6]$.

Следует отметить что в первом полугодии 2016 г., был зафиксирован естественный прирост численности населения: при почти 9,5 миллиона человек популяции, в 2015-м родилось 119 тысяч детей и одновременно увеличился размер белорусской семьи: более половины рожденных детей - это вторые, третьи и последующие дети. Уровень рождаемости увеличился до 12,5 промилле, что выше, чем во многих европейских государствах. Это стало возможным благодаря тому, что в стране, несмотря на снижение численности женщин репродуктивного возраста (с 2013 г.), становится все больше многодетных семей. Так, если сравнивать с данными переписи 2009 г., когда насчитывалось 62,5 тыс. многодетных семей, то в 2016 году насчитывалось 85 тыс., а на начало 2019 года эта цифра составила уже 110 тыс., а в Минске по данным на 1 октября 2019 года, проживают более 15,5 тыс. многодетных семей, воспитывающих 3-х и более ребенка. Хотя уже наступил период сокращения численности женщин репродуктивного возраста (15-49 лет), в том числе наиболее активного (20-29 лет), на долю которых приходится почти 60 процентов всех рождений, увеличивается численность женщин в возрасте 30-39 лет, на долю которых приходится свыше 30 процентов всех рождений вторых и третьих детей. Специалисты делают вывод о том, что сохранился потенциал для роста рождаемости. Еще одна из тенденций - увеличивается средний возраст матери при рождении ребенка. В 2019 году средний возраст матери при рождении ребенка в стране был 29,4 года (средний возраст при рождении первого малыша - 26,7), а средний возраст рождения ребенка в 1990 году был 25,3 года, в 2000- 25,6 года, в $2010-27,3$, в 2015 году 28,6 года, а при рождении первого ребенка - 26 лет. По данным статистики РБ, позже всего рожают в Минске: средний возраст при рождении ребенка здесь 30,7 (первого 28,5). Раньше всего рожают первого ребенка в Брестской области - в среднем в 25,9. Это свидетельствует о том, что современная женщина сначала получает образование, строит карьеру, а затем создает семью. Поэтому в демографической политике следует учитывать индикаторы возрастной структуры женщин активного детородного возраста и их социальный статус и семейные практики в отношении рождения детей, репродуктивное поведение [1].

Жители Беларуси, по результатам проведенного эмпирического исследования (в указанной работе были представлены результаты социологического исследования, проведенного Институтом социологии НАН Беларуси в марте 2015 г. по национальной репрезентативной выборке (1499 человек), не мотивированы на расширенное репродуктивное поведение. Причем чем моложе респондент, тем менышее количество детей он называет «идеальным» для белорусской семьи [4, с. 308], (Рис. 1.). 


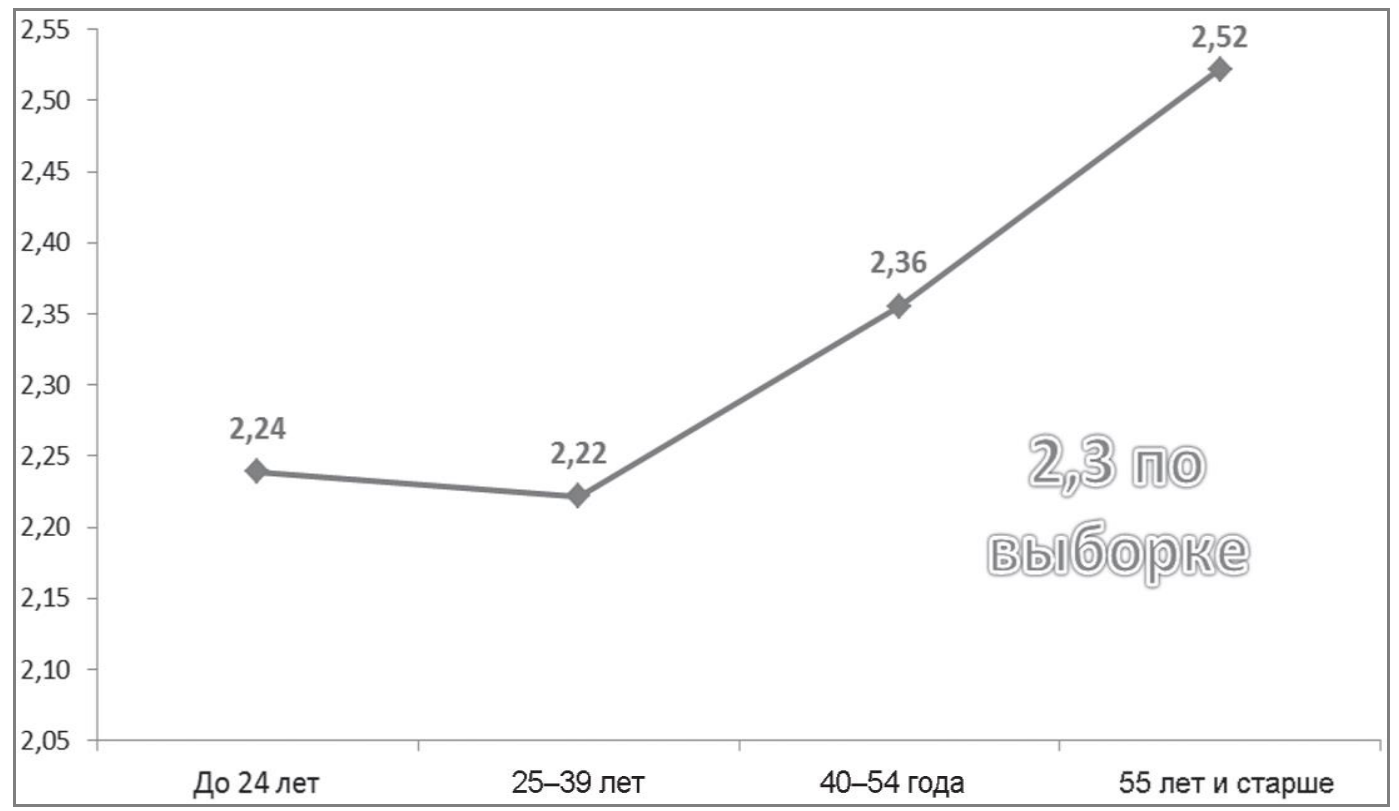

Рисунок 1. Идеальное количество детей в семье в представлении белорусов (среднее значение)

Источник: Институт социологии НАН Беларуси, 2015 г.

Среди факторов, оказывающих влияние на расширенное воспроизводство, то есть желание иметь троих и более детей, наиболее значимыми, по сравнению с остальными, являются принадлежность супругов к определенной культуре, их религиозные убеждения. Бездетными семыи становятся в основном из-за состояния.

Также увеличению количества многодетных семей способствуют меры государственной социальной поддержки: льготное жилье, материальная помощь. С середины 2000-хгодов правительство активно поддерживало социальный пакет для семей с детьми. Ежемесячные пособия увеличились, появилось пособие на ребенка старше 3 лет (если в семье воспитывается ребенок до 3 лет), семейный капитал, жилищные льготы. В 2013 году размер пособия по уходу за ребенком привязали к средней заработной плате в стране. В 2015 г. было введено дополнительное пособие на ребенка старше 3 лет в семьях, где воспитывается ребенок до 3 лет, что увеличило общий объем финансовых выплат семьям с детьми до 3 лет. С 1 января 2015 года была введена выплата семейного капитала в размере 10 тыс. долларов США при рождении, усыновлении или удочерении 3-го или последующих детей. Семейный капитал выплачивается один раз. При этом данные средства можно потратить только на определенные цели: улучшение жилищных условий; получение образования; получение услуг в сфере социального обслуживания, здравоохранения; формирование накопительной (дополнительной) пенсии матери, мачехи или родителя в неполной семье. С 2020 года семейный капитал будет выплачиваться в белорусских рублях и составит уже почти 11 тыс. долларов США.

Но не всегда исключительно финансовые и материальные условия влияют на репродуктивное поведение. Согласно результатов социологического исследования, проведенного Институтом социологии НАН Беларуси в марте 2015 г. по национальной репрезентативной выборке (1499 человек), ответы респондентов на готовность иметь детей распределились следующим образом [4, с. 308], (Puc. 2.): 


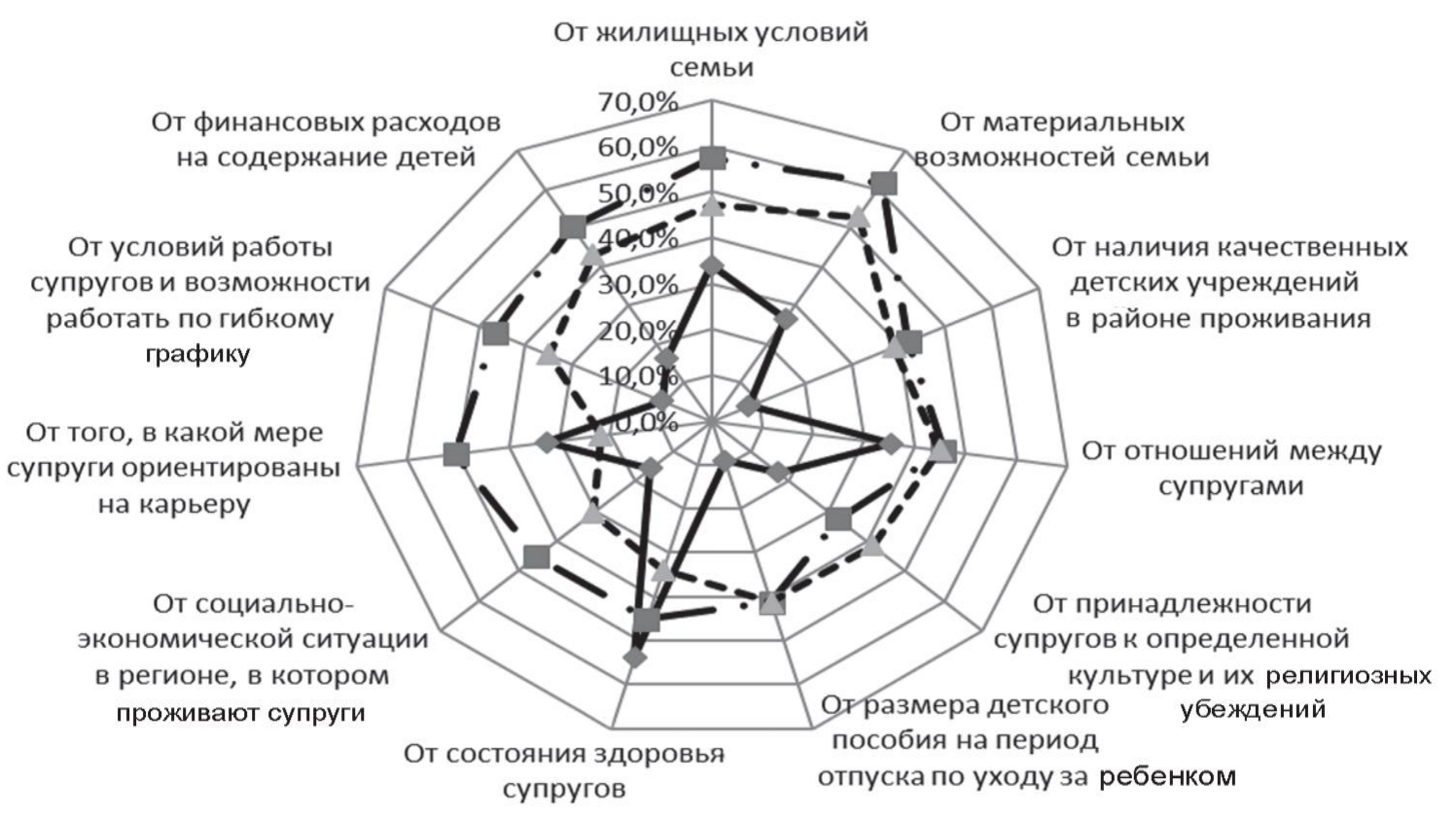

- - Не иметь детей

Иметь одного ребенка

- - Иметь троих и более детей

Рисунок 2. Факторы, оказывающие влияние на репродуктивное поведение белорусов Источник: Институт социологии НАН Беларуси, 2015 г.

Таким образом, к факторам, влияющим на репродуктивное поведение и рождаемость населения относятся: жизненные цели, семья, желание супругов, финансовые и жилищные условия, помощь государства, религиозность, психологические установки и многие другие.

За последующие периоды были приняты уже три национальные программы демографического развития. Первые две программы были направлены в первую очередь на стимулирование рождаемости, национальное законодательство в этой области направлено на социально-экономическую поддержку семей в связи с рождением и воспитанием детей: матери могут находиться в оплачиваемом отпуске по уходу за ребенком до достижения им 3 лет, в Беларуси низкая младенческая смертность (на уровне развитых европейских стран), практически удалось ликвидировать материнскую смертность.

В 2016 году была принята новая государственная программа «Здоровье народа и демографическая безопасность на 2016-2020 годы». Ее основная цель - стабилизации численности населения и увеличения ожидаемой продолжительности жизни и сохранение и укрепление здоровья народа. В программу включено семь подпрограмм: охрана здоровья матери и ребенка, улучшение условий жизнедеятельности семей с детьми, обеспечение профилактики неинфекционных заболеваний на протяжении всей жизни человека, снижение уровня негативных социальных и экономических последствий пьянства и алкоголизма, профилактика ВИЧ-инфекции и другие. Одно из главных отличий государственной программы от предыдущих, это:

$\checkmark$ акцент на информирование в целях пропаганды здорового образа жизни;

$\checkmark$ поддержание и стимулирование самосохранительного поведения граждан;

$\checkmark$ формирование в обществе позитивного образа семьи с детьми;

$\checkmark$ повышение авторитета материнства и отцовства.

Принятая на 2016-2020 годы Государственная программа «Здоровье народа и демографическая безопасность Республики Беларусь» разработана в соответствии Основными положениями программы социально-экономического развития Республики 
Беларусь на 2016-2020 годы, пункт 5.5. «Повышение уровня здоровья белорусских граждан и доступности медицинских услуг». Эта программа направлена на развитие человеческого потенциала и повышение качества жизни населения за счет создания условий для обеспечения достойного уровня и качества жизни на основе улучшения демографического потенциала и повышения качества и доступности здравоохранения и одновременно связана с приоритетными направлениями социально-экономического развития, определенными в Национальной стратегии устойчивого развития до 2020 г. (далее - НСУР-2020) и уточненными в Концепции Национальной стратегии устойчивого развития до 2030 г. (далее - Концепция НСУР-2030).

Здесь прослеживается взаимосвязь концепции устойчивого развития с деятельностью государства в направлении повышения качества жизни населения: в НСУР-2020 переход к устойчивому развитию связывается с улучшением физического и репродуктивного здоровья, созданием предпосылок для повышения рождаемости и увеличения ожидаемой продолжительности жизни, всесторонним укреплением института семьи. В Концепции НСУР-2030 стабилизация численности населения республики и увеличение ожидаемой продолжительности жизни представляются как одна из целей устойчивого развития в среднесрочной перспективе (2016-2020 гг.).

Данные программные документы предусматривают:

улучшение воспроизводства и здоровья населения;

$\checkmark$ повышение творческой активности населения;

$\checkmark$ создание благоприятных условий для жизнедеятельности семей;

$\checkmark$ регулирование миграционного поведения населения (НСУР-2020);

$\checkmark$ развитие и укрепление семейных ценностей;

$\checkmark$ повышение престижа родительского труда по воспитанию нескольких детей;

$\checkmark$ создание дружественных семье условий для сочетания трудовой деятельности с семейными обязанностями;

$\checkmark$ совершенствование форм социальной защиты семей с детьми в направлении усиления ее адресности;

$\checkmark$ переориентацию медицинской помощи на здоровье здорового человека (Концепция НСУР-2030).

Реализация государственной политики в области демографической безопасности предполагает осуществление системы конкретных мер и механизмов, направленных на предотвращение демографических угроз. В первую очередь это:

- мониторинг угроз демографической безопасности;

- прогнозирование факторов, определяющих эти угрозы;

- подготовка комплексных государственных мер по обеспечению демографической безопасности путем разработки и реализации демографических программ и прогнозов на кратко-, средне- и долгосрочную перспективу.

Один из демографических индикаторов, которому уделяется особое внимание, это мужское здоровье, так как согласно статистических данных, порядка 80 процентов умирающих в трудоспособном возрасте это мужчины. Если общемировые данные показывают, что мужчины живут на 4 года меньше, чем женщины, то в Беларуси эта разница составляет более 10 лет. Среди причин смерти мужчин специалисты отмечают: дорожнотранспортный травматизм, убийства, травмы, отравления. Все это отражается и в интегральных показателях ожидаемой продолжительности предстоящей жизни. Именно с учетом этого, в государственной программе «Здоровье народа и демографическая безопасность» впервые масштабно обозначены вопросы мужского здоровья. 
Еще один фактор над которым следует работать, это то, что для Беларуси, как и для других европейских государств, характерен высокий уровень урбанизации. На начало 2016 года 77,6 процента населения республики проживало в городах, 22,4 процент — в сельской местности, на начало 2019 года это - 78,4 и 21,6 соответственно. В городах доля лиц старше трудоспособного возраста составляет 22,7 процента, в сельской местности - свыше 32 процентов, то есть почти каждый третий сельский житель пенсионер. Существенные различия отмечаются в возрастной структуре населения по полу в разрезе городской и сельской местности. При этом в городах численность мужчин до 30 лет превышает число женщин, в сельской местности это наблюдается до 55 лет. Это связано с высокой долей девушек в миграции сельского населения: в результате в городе - дефицит юношей, в сельской местности - девушек. Сегодня разрабатываются меры государственной поддержки, создаются условия для того, чтобы представители сельской молодежи, которые выезжали в города и областные центры на обучение возвращалась домой. Как отмечала Л.П,Шахотько «В городах существенно выше, чем в сельской местности, доля средних домохозяйств, состоящих из трех и четырех человек. Тогда как в сельской местности значительно больше доля малочисленных домохозяйств, состоящих из одного и двух человек, а также больших домохозяйств, состоящих из пяти человек и более. Превышение в сельской местности доли домохозяйств, состоящих из одного-двух человек, связано с более интенсивным старением населения в сельской местности, а также с тем, что значительная часть сельской молодежи после школы выезжает в города на учебу. В сельской местности остаются родители, дети которых выехали в город на учебу или работу, т. е. так называемые семьи пустого гнезда. Превышение же в сельской местности доли больших домохозяйств, состоящих из пяти человек и более, обусловлено тем, что здесь среди домохозяйств, состоящих из супружеской пары с детьми до 18 лет, значительно больше, чем в городах, доля тех, у которых трое детей и более» [8, с. 31$]$.

Основными источниками демографической информации являются: - переписи населения (в РБ в октябре 2019 года проводилась очередная перепись); - текущий учет демографических событий; - выборочные (специальные) обследования отдельных граждан либо домохозяйств; - регистры населения.

Также существуют различные подходы и методы изучения и классификации населения. Наиболее репрезентативным из которых является анализ структуры общества с учетом социально-экономической ситуации. Исходя из этого, рассматривается половозрастная структура общества, ее изменения, соотношение работающих и пенсионеров. Bce это позволит прогнозировать дальнейшие демографические изменения в обществе. Динамика изменения демографической ситуации может быть представлена следующим образом (Таблица 1.):

Таблица1. Численность и естественный прирост населения:

на начало года; тыс. человек

\begin{tabular}{|l|c|c|c|c|c|}
\hline \multicolumn{1}{|c|}{ Показатели/год } & $\mathbf{2 0 1 5}$ & $\mathbf{2 0 1 6}$ & $\mathbf{2 0 1 7}$ & $\mathbf{2 0 1 8}$ & $\mathbf{2 0 1 9 *}$ \\
\hline Численность населения & 9481 & 9498 & 9505 & 9492 & 9475 \\
\hline в том числе: & 4409 & 4421 & 4427 & 4422 & 4416 \\
\hline мужчины & 5072 & 5077 & 5078 & 5070 & 5059 \\
\hline женщины & & & & & \\
\hline Всего в возрасте: & & & & & \\
\hline
\end{tabular}




\begin{tabular}{|c|c|c|c|c|c|}
\hline $\begin{array}{l}\text { моложе трудоспособного } \\
(0-15)\end{array}$ & 1610 & 1641 & 1669 & 1683 & 1691 \\
\hline трудоспособном & 5560 & 5499 & 5432 & 5432 & 5434 \\
\hline старше трудоспособного & 2311 & 2358 & 2404 & 2377 & 2350 \\
\hline \multicolumn{6}{|c|}{ Удельный вес в общей численности населения, процентов } \\
\hline городского & 77,3 & 77,6 & 77,9 & 78,1 & 78,4 \\
\hline сельского & 22,7 & 22,4 & 22,1 & 21,9 & 21,6 \\
\hline $\begin{array}{l}\text { Естественный прирост, } \\
\text { убыль (-) населения, } \\
\text { тыс. человек }\end{array}$ & $-1,0$ & $-1,6$ & $-16,7$ & $-26,0$ & $\ldots$ \\
\hline
\end{tabular}

*) начало года, до переписи населения.

Источник: Белстат

По сути, в таблице отражены основные социально-демографические индикаторы и они, к сожалению, повторяют во многом все тенденции депопуляции, имеющиеся в мире. В 2019 году произошло небольшое общее снижение численности населения Беларуси по сравнению с 2015 годом (на 5,7 тысяч человек или 0,47\%).

В приведенной статистической информации также хорошо заметны три важные общественные тенденции: миграция населения из сельской местности в города, снижение рождаемости и рост смертности. Такой уровень сочетания рождаемости и смертности означает увеличение числа пожилых в общей массе населения. Это, в свою очередь, ведет к старению нации и углублению экономических проблем.

В том числе и с целью привлечения международного опыта решения демографических проблем, Республика Беларусь в 2015 году (совместно с еще 193 государствами) одобрила Повестку дня в области устойчивого развития на период до 2030 года (далее - Повестка-2030). Повестка-2030 для Беларуси, это новый механизм глобальной политики в области устойчивого развития, которая призвана обеспечить реальный прогресс в борьбе с нищетой, голодом, детской смертностью, эпидемиями, изменением климата и иными вызовами современности, а также способствовать обеспечению мира и безопасности на планете. Инструментами ее реализации выступают 17 Целей устойчивого развития тысячелетия:

1. Повсеместная ликвидация нищеты во всех её формах;

2. Ликвидация голода, обеспечение продовольственной безопасности и улучшение питания и содействие устойчивому развитию сельского хозяйства;

3. Обеспечение здорового образа жизни и содействие благополучию для всех в любом возрасте;

4. Обеспечение всеохватного и справедливого качественного образования и поощрение возможности обучения на протяжении всей жизни для всех;

5. Обеспечение гендерного равенства и расширение прав и возможностей всех женщин и девочек;

6. Обеспечение наличия и рациональное использование водных ресурсов и санитарии для всех; 
7. Обеспечение доступа к недорогостоящим, надежным, устойчивым и современным источникам энергии для всех;

8. Содействие неуклонному, всеохватному и устойчивому экономическому росту, полной и производительной занятости и достойной работе для всех;

9. Создание прочной инфраструктуры, содействие обеспечению всеохватной и устойчивой индустриализации и внедрению инноваций;

10.Снижение уровня неравенства внутри стран и между ними;

11.Обеспечение открытости, безопасности, жизнестойкости и устойчивости городов и населенных пунктов;

12.Обеспечение рациональных моделей потребления и производства;

13.Принятие срочных мер по борьбе с изменением климата и его последствиями;

14.Сохранение и рациональное использование океанов, морей и морских ресурсов в интересах устойчивого развития;

15.Защита, восстановление экосистем суши и содействие их рациональному использованию, рациональное управление лесами, борьба с опустыниванием, прекращение и обращение вспять процесса деградации земель и прекращение процесса утраты биологического разнообразия;

16. Содействие построению миролюбивых и открытых обществ в интересах устойчивого развития, обеспечение доступа к правосудию для всех и создание эффективных, подотчетных и основанных на широком участии учреждений на всех уровнях;

17. Укрепление средств достижения устойчивого развития и активизация работы механизмов глобального партнерства в интересах устойчивого развития [7].

Страна активно приступила к работе по имплементации Целей устойчивого развития на национальном уровне, что включает в себя формирование целостной стратегии устойчивого развития на основе принципа национальной ответственности, а также создание соответствующих институциональных механизмов. Основные задачи НСУР:

$\checkmark$ трансформация модели национальной экономики от административного к индикативному планированию,

$\checkmark$ достижение баланса вклада государственной и частной собственности в формирование валового внутреннего продукта и развитие национальной экономики,

$\checkmark$ внедрение принципов "зеленой экономики“" в производство, инновационное развитие,

$\checkmark$ социальная поддержка наиболее нуждающихся

$\checkmark$ создание условий для реализации личностного потенциала каждого человека.

Вторым важным документом в данной области является принятая в декабре 2016 года Программа социально-экономического развития Республики Беларусь на 2016-2020 годы. В качестве основы устойчивого развития Программа определяет максимально эффективное использование внутренних ресурсов, включая инновационные возможности экономики и развитие человеческого потенциала. Согласно данному документу главная задача в области развития - повышение качества жизни населения на основе роста конкурентоспособности экономики, привлечения инвестиций и инновационного развития. Ниже приведем данные по численности занятого населения по видам экономической деятельности в 2018 г. (табл.2)

Таблица 2. Численность занятого населения по видам экономической деятельности

\begin{tabular}{|c|c|c|c|c|}
\hline $\begin{array}{c}\text { Численность занятого населения по видам } \\
\text { экономической деятельности (в процентах } \\
\text { к итогу) }\end{array}$ & 2015 & 2016 & 2017 & 2018 \\
\hline
\end{tabular}




\begin{tabular}{|c|c|c|c|c|}
\hline Занято в экономике - всего & 100 & 100 & 100 & 100 \\
\hline \multicolumn{5}{|l|}{ в том числе: } \\
\hline сельское, лесное и рыбное хозяйство & 9,6 & 9,6 & 9,6 & 9,3 \\
\hline промышленность & 23,7 & 23,3 & 23,5 & 23,5 \\
\hline горнодобывающая промышленность & 0,3 & 0,2 & 0,2 & 0,2 \\
\hline обрабатывающая промышленность & 20,2 & 19,8 & 19,9 & 20,0 \\
\hline $\begin{array}{l}\text { снабжение электроэнергией, газом, паром, } \\
\text { горячей водой } \\
\text { и кондиционированным воздухом }\end{array}$ & 2,3 & 2,2 & 2,3 & 2,2 \\
\hline $\begin{array}{l}\text { водоснабжение; сбор, обработка и удаление } \\
\text { отходов, деятельность по ликвидации } \\
\text { загрязнений }\end{array}$ & 0,9 & 1,1 & 1,1 & 1,1 \\
\hline строительство & 7,8 & 7,0 & 6,4 & 6,3 \\
\hline $\begin{array}{l}\text { оптовая и розничная торговля; ремонт } \\
\text { автомобилей } \\
\text { и мотоциклов }\end{array}$ & 14,5 & 14,4 & 14,2 & 14,4 \\
\hline $\begin{array}{l}\text { транспортная деятельность, складирование, } \\
\text { почтовая } \\
\text { и курьерская деятельность }\end{array}$ & 6,7 & 6,7 & 6,9 & 6,9 \\
\hline $\begin{array}{l}\text { услуги по временному проживанию и } \\
\text { питанию }\end{array}$ & 2,1 & 2,2 & 2,2 & 2,2 \\
\hline информация и связь & 2,1 & 2,2 & 2,4 & 2,5 \\
\hline финансовая и страховая деятельность & 1,7 & 1,6 & 1,6 & 1,6 \\
\hline операции с недвижимым имуществом & 1,8 & 2,0 & 1,8 & 1,7 \\
\hline $\begin{array}{l}\text { профессиональная, научная } \\
\text { и техническая деятельность }\end{array}$ & 3,0 & 3,1 & 3,2 & 3,2 \\
\hline $\begin{array}{l}\text { деятельность в сфере административных } \\
\text { и вспомогательных услуг }\end{array}$ & 2,3 & 2,1 & 2,3 & 2,4 \\
\hline государственное управление & 4,1 & 4,3 & 4,2 & 4,2 \\
\hline образование & 10,0 & 10,3 & 10,4 & 10,4 \\
\hline здравоохранение и социальные услуги & 7,0 & 7,3 & 7,4 & 7,5 \\
\hline $\begin{array}{l}\text { творчество, спорт, развлечения } \\
\text { и отдых }\end{array}$ & 2,0 & 2,1 & 2,1 & 2,0 \\
\hline
\end{tabular}




\begin{tabular}{|l|c|c|c|c|}
\hline предоставление прочих видов услуг & 1,5 & 1,7 & 1,7 & 1,7 \\
\hline $\begin{array}{l}\text { деятельность частных домашних хозяйств, } \\
\begin{array}{l}\text { пронимающих домашнюю прислугу и } \\
\text { собственного потребления }\end{array}\end{array}$ & 0,1 & 0,1 & 0,1 & 0,2 \\
\hline
\end{tabular}

Источник: Белстат

Как видно из таблицы, производством материальных благ занимаются только три первые категории и там же концентрируется экспортная составляющая. Это говорит о несбалансированности экономики и об опасности кризисных явлений в обществе. Хотя реализации ЦУР 8 «Достойная работа и экономический рост» будет способствовать решение таких задач, как обеспечение эффективной занятости, создание высокопроизводительных рабочих мест, улучшение условий труда, рост доходов и благосостояния населения. Номинальная начисленная среднемесячная заработная плата работников Республики Беларусь за 2018 год, без учета микро- и малых организаций без ведомственной подчиненности составила 958,1 рублей. [7].

Согласно данных Комитета по статистике, средний возраст занятых в 2018 году составил 40,6 года. Максимальный уровень занятости наблюдается в возрастной группе от 30 до 34 лет (91,5\%). Удельный вес молодежи в возрасте до 31 года составил 24,2\% [2], (Рuc. 3.).

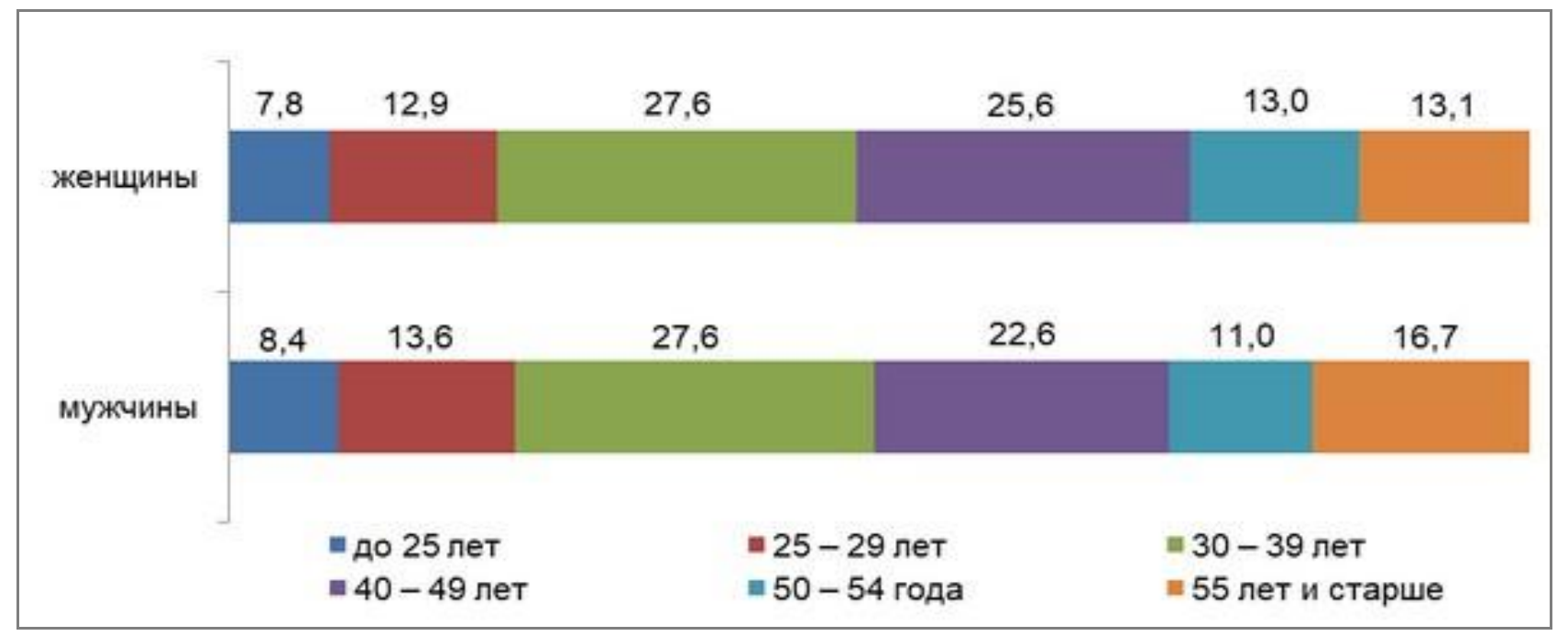

Рисунок 3. Распределение численности занятого населения по полу и возрастным группам в 2018 году

Источник: Белстат

Также Белстат, с целью подготовки странового отчета по ЦУР проанализировал первичные показатели национального перечня показателей достижения целей устойчивого развития [7] (Рис. 4.). 


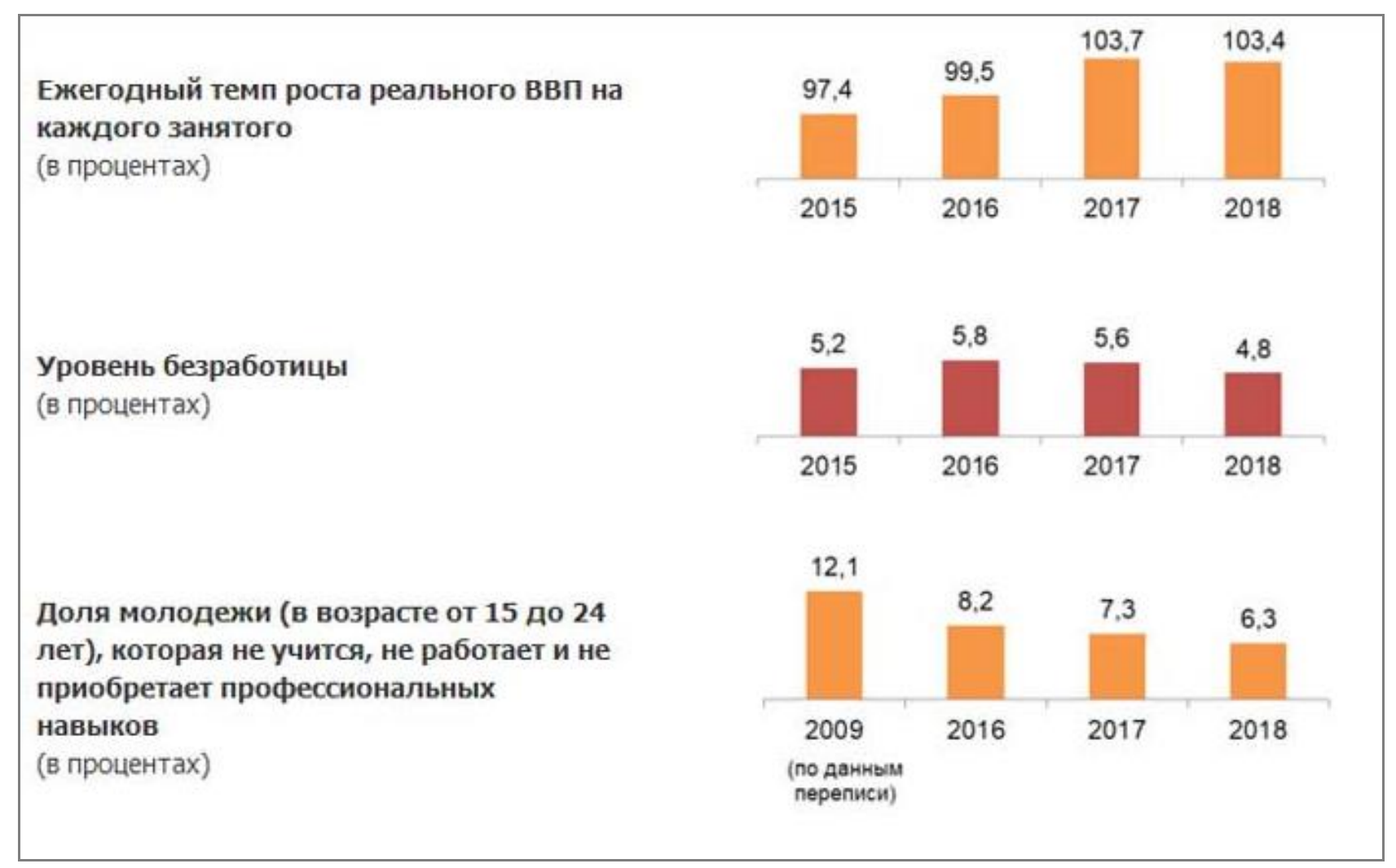

Доля молодежи (в возрасте от 15 до 24

лет), которая не учится, не работает и не

нальных

навыков

Рисунок 4. Отдельные показатели национального перечня показателей

Источник: Белстат достижения целей устойчивого развития Республики Беларусь

Для достижения поставленных целей развития страны будет основываться на следующих приоритетах: обеспечение устойчивого экономического роста на основе инвестиций и инноваций, инвестиции в развитие человеческого потенциала и укрепление социальной поддержки уязвимых групп, обеспечение гендерного равенства и активная молодежная политика, поддержание экологической устойчивости. Ключевые государственные программы и стратегии, а также иные программные документы будут реализовываться с учетом ЦУР, их выполнение будет отслеживаться с помощью показателей, разработанных в национальной системе мониторинга и оценки хода осуществления. Беларусь уже представила первый отчет о реализации целей устойчивого развития. Но есть еще целый ряд показателей, которых не удалось достичь.

Исследование качества и уровня жизни населения отдельной страны в контексте современных демографических вызовов в наше время очень актуально. Благодаря этим исследованиям можно имплементировать международный опыт, можно сделать выводы о качестве жизни отдельных категорий граждан, об уровне устойчивого развития, о наличии и отсутствии роста в той или иной стране. Мониторинг качества жизни в контексте Целей устойчивого развития служит основой для принятия регулирующих мер в соответствующих областях экономической и социальной политики. Но без унификации, выработки единых социальных стандартов и подходов в культуре, образовании, здравоохранении, обеспечения занятости населения, достойного уровня доходов работающих граждан и достойной пенсии это нереализуемо.

\section{Библиография}

1. Демографический ежегодник Республики Беларусь: стат. сб. Минск: Нац. стат. ком. Респ. Беларусь, 2016, 442 с. 
2. Демографический ежегодник Республики Беларусь: стат. сб. Минск: Нац. стат. ком. Республики Беларусь, 2018, 431 с.

3. Злотников А.Г. Факторы современного демографического развития Беларуси. Демографические проблемы Беларуси и духовно-нравственное здоровье нации: матер. науч. конф. Гомель, 2005, с. 20-24.

4. Каргаполова Е.В., Лашук И.В. Семья как ценность современного общества (по итогам социологических исследований в Астраханской области Российской Федерации и в Республике Беларусь. Социологический Альманах, 2018, № 9, с. 305-314.

5. Об утверждении Концепции национальной безопасности Республики Беларусь [Электронный ресурс]: Указ Президента Респ. Беларусь, 9 нояб. 2010 г., № 575. Консультант Плюс. Беларусь, ООО «ЮрСпектр», Нац. центр правовой информ. Респ. Беларусь. Минск, 2016.

6. Об утверждении Национальной программы демографической безопасности Республики Беларусь на 2007-2010 годы [Электронный ресурс]: Указ Президента Респ. Беларусь, 26 марта 2007 г., № 135. Консультант Плюс. Беларусь, ООО «ЮрСпектр», Нац. центр правовой информ. Респ. Беларусь. Минск, 2016.

7. Повестка дня в области Устойчивого Развития на период до 2030 года. https://www.by.undp.org/content/belarus/ru/home/post-2015/sdg-overview.html [Электронный peсурс]. Режим доступа: https://www.by.undp.org/content/belarus/ru/home/post html. (дата доступа: 13.10.2019).

8. Шахотько Л., Шахотько Д. Домохозяйство, семья и семейная политика в Беларуси. Минск: «Беларуская навука», 2018, 400 с. 